\title{
CMMI and IDEAL in Software Process Improvement
}

\author{
SUSSY BAYONA-ORÉ ${ }^{1,2}$, JOSSELYN CHAMILCO $^{2}$, DAYVIS PEREZ ${ }^{2}$ \\ ${ }^{1}$ Dirección de Investigación, Universidad Autónoma del Perú. Lima-Perú \\ ${ }^{2}$ Facultad de Ingeniería y Arquitectura, Universidad San Martin de Porres. \\ Lima, PERU
}

\begin{abstract}
Different models and standards have been developed with the purpose of improving software development processes and obtaining quality products and achieving customer satisfaction. Despite the efforts that organizations make, they do not always achieve these results. In this article we present the results of the implementation of best practices established by the CMMI model using the IDEAL methodology and SCAMPI B method. The results show that applying best practices helps organizations to improve their processes, minimize the number of defects and increase customer satisfaction. Likewise, the critical factors that were considered and aspects to be considered in the deployment of processes are presented.
\end{abstract}

Key-Words: - CMMI, process improvement, IDEAL, SCAMPI, lessons learned, critical factors.

Received: December 13, 2019. Revised: March 19, 2020. Accepted: March 25, 2020. Published: March 31, 2020.

\section{Introduction}

Organizations are increasingly incorporating information technologies to automate administrative, financial and core business processes. Nowadays, software products are demanded to be of quality and the best practices come from international models and/or standards focused on the improvement of processes for software development are applied.

In the process of developing a software product, one of the most important phases is requirements management. Requirements management encompasses the tasks of establishing a requirements baseline and maintaining traceability, change control, and configuration management [1].

Several models and standards oriented to process improvement have been proposed, among them the CMMI DEV 1.3 model [2] for process improvement, the IEEE 830 standard [3] for requirements specification, ISO/IEC 12207 [4] for software development, among others. CMMI is a widely recognized reference model for software quality and process improvement [5] consisting of 22 process areas. The implementation of the best practices established by CMMI leads to process improvement [6].

Among the process areas of CMMI are: Requirements Management; Verification and Validation. The importance of requirements management has been recognized because of the risks associated if the project is not managed correctly [7] and because it is a discipline that has the greatest impact on project failure [8]. Software quality and customer satisfaction is related to requirements management. Inadequate and unclear requirements have been reported by the Chaos study as a cause of unsuccessful projects [9]. In addition, the changing nature of requirements requires managing these changes throughout software development because of their impact on software quality [7]. Achieving quality products through process quality generates great value in a competitive market [10].

The implementation of the best practices of the CMMI model requires a methodology such as IDEAL [11] and SCAMPI as a methodology to evaluate the state of the practices in the organization. The process of implementing CMMI best practices is conditioned by several factors [12] because it is a change and must be managed. The pillars for change management, among others, are training, communication and participation of people who are interested.

The purpose of this research is to determine the impact of implementing the best practices established by CMMI for requirements management, verification and validation. Reducing defects improves software quality, which is one of the characteristics that software development organizations value [13]. The most common causes of requirements-related problems are the lack of requirements management and leadership skills [14].

This article has been structured in 5 sections that include the introduction. Section 2 presents the theoretical framework, Section 3 presents the methodology used. Section 4 presents the results. Finally, the conclusions are presented. 


\section{Background}

The Capacity Maturity Model (CMM) is a process assessment model of an organization. It was initially developed for the processes related to the development and implementation of software of the SEI (Software Engineering Institute). It is a simplified representation of the world and contains the essential elements of effective processes. These elements are based on the concepts developed by Crosby, Deming, Juran and Humphrey.

\subsection{CMMI}

CMMI is a model that provides a set of best practices for the improvement and evaluation of processes for the development, maintenance and operation of systems [2]. CMMI consists of 22 Process Areas. The Process Areas are structured with Specific Goals, Specific Practices and Subpractices (see Fig. 1).

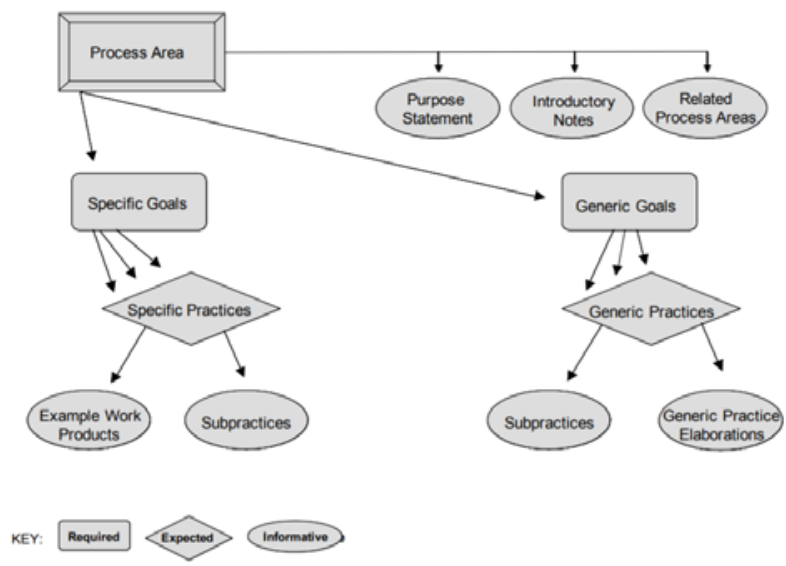

Fig. 1. Structure of Process Area [2].

The achievement of specific and generic goals associated to each predefined set of process areas are distributed in the following levels: Level 1 Initial, level 2 Managed level, Level 3 Defined level, Level 4 Quantitatively Managed level, and Level 5 Optimizing level.

Each Process Area consists of a definition of the purpose, introductory notes and the related process areas. A Process Area has Specific Goals and Generic Goals. Each Specific Goal has a set of
Specific Practices. The Specific Practices have Subpractices and Examples Work Products.

\subsection{IDEAL}

IDEAL is a model for initiating, planning and implementing improvement actions. The model consists of five phases: Initiate, Diagnose, Establish, Act and Learn [11]. Table 2 presents each of the phases of the IDEAL model (See Fig. 2).

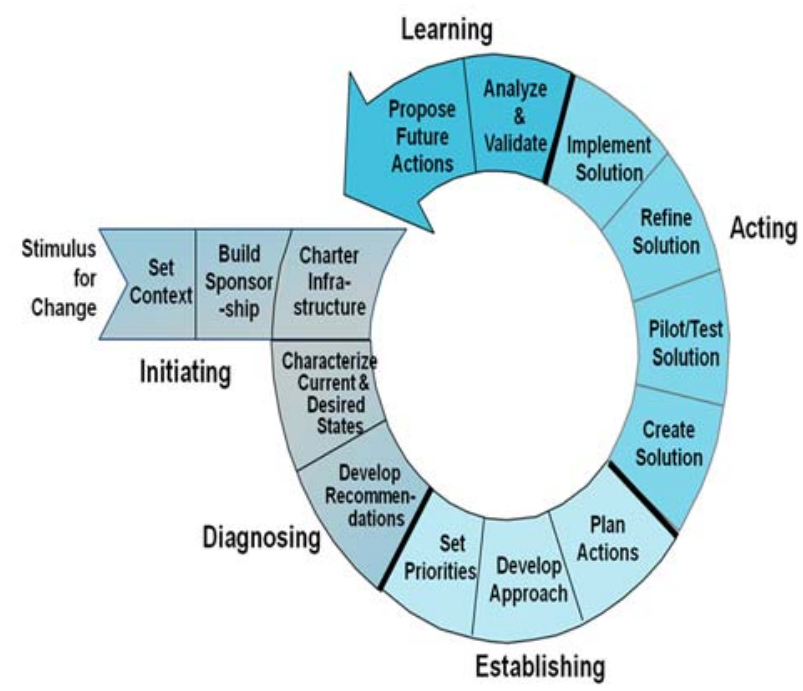

Fig. 2. IDEAL model

\subsection{SCAMPI}

The SCAMPI method (Standard CMMI Appraisal Method for Process Improvement) is a method developed by the SEI (Software Engineering Institute) that allows to identify the strengths and weaknesses of current software processes based on CMMI models. There are three types of SCAMPI A, $B$ and C. SCAMPI $B$ allows to identify the implementation of the process in the organization with a wider sample of information, but it does not give a level of maturity like SCAMPI A that allows to see the institutionalization of the processes. SCAMPI B provides an insight into the practices actually used in the organisation and the status of these. In this way, strengths and weaknesses are related to the CMMI model.

Table 1: Phases of the IDEAL Model

\begin{tabular}{|l|l|}
\hline Phases & Description \\
\hline $\begin{array}{l}\text { Phase } \\
\text { Initiating }\end{array}$ & $\begin{array}{l}\text { In this phase, the needs of the company's change are identified. It is determined what is the } \\
\text { stimulus for the development of the improvement, the goals and objectives are established and } \\
\text { the benefits to be obtained. The sponsor of the project is determined and the commitment to the } \\
\text { improvement process is obtained and ensured. The structure and infrastructure to support the }\end{array}$ \\
\hline
\end{tabular}




\begin{tabular}{|l|l|}
\hline Phases & Description \\
\hline $\begin{array}{l}\text { Phase 2: } \\
\text { Diagnosing }\end{array}$ & $\begin{array}{l}\text { In this phase, the process areas are evaluated in order to diagnose the level of compliance with } \\
\text { best practices for each of the process areas. The questionnaire is developed based on the goals } \\
\text { and specific practices of each process area. Interviews are conducted based on the } \\
\text { questionnaire to determine the gaps. The results are analyzed, the desired future of the } \\
\text { organization is established and recommendations are developed to define the activities to be } \\
\text { carried out. }\end{array}$ \\
\hline $\begin{array}{l}\text { Phase 3: } \\
\text { Establishing }\end{array}$ & $\begin{array}{l}\text { In this phase, action plans are proposed for each area and priorities are established taking into } \\
\text { account the recommendations of Phase 2, strategies are determined to identify the availability } \\
\text { of resources and the action plan is developed which includes resources, follow-up mechanisms, } \\
\text { risks and mitigation strategies. }\end{array}$ \\
\hline $\begin{array}{l}\text { Phase } \\
\text { Acting }\end{array}$ & $\begin{array}{l}\text { In this phase, the solution is established, pilot tests are carried out, the solution is refined and } \\
\text { the lessons learned are collected and the solution is implemented in the organization's } \\
\text { development projects. }\end{array}$ \\
\hline $\begin{array}{l}\text { Phase } \\
\text { Learning }\end{array}$ & $\begin{array}{l}\text { In this phase all the information that was collected before, during and after the development of } \\
\text { the project is analyzed and future actions are proposed, recommendations based on the analysis } \\
\text { that will serve as feedback for the continuous improvement of the processes. }\end{array}$ \\
\hline
\end{tabular}

\subsection{Lessons Learned}

The lessons learned are the experiences acquired in the execution of deployment processes that can add value to similar processes in the future. The OECD defines a lesson learned as generalizations resulting from experience in a specific situation that can be applied to broader situations. According to McIntyre [15] lessons learned refer to the act of learning from experience.

Best practices are the attributes that have proven to be effective guides to the success of an organization's processes or projects. A lesson learned can become best practice after a process of assessment and comparison with other experiences.

\section{Method}

To start the improvement process, a process improvement team was formed with the support of the institution's Project Office. The clients who participated in the improvement process were

- The Project Sponsor: For the approval of the plan for the implementation of the best practices.

- Improvement Project Leader: Responsible for the creation and maintenance of the plan. He is the one who establishes the guidelines for the follow up and control of the project implementation.

- The Process Improvement Team: Responsible and facilitator for activities related to process improvement, such as planning improvement actions, defining processes, supervising and supporting the implementation of improvements.

- The Quality Assurance Team: responsible for the follow-up and supervision during the implementation of the processes and solutions defined validating compliance in the project.

- Work Team Leader: responsible for the work group in terms of compliance with the objectives and results of the work unit.

- Work Team: in charge of evaluating, defining, implementing, leading, proposing improvements, documenting processes and the solutions that are defined.

IDEAL was used to carry out the implementation of the best practices. The SCAMPI method was used to establish the gaps between the organization's practices and the best practices of CCMI, which allows the identification of the strengths and weaknesses of the organization's current processes.

To define the current state of the organization, data is collected and documentation is analyzed, in order to identify critical areas. In [16], the phases of the gap analysis between the specific and generic goals established by CMMI and the practices of the organization are presented for each process area. The statistical test is Wilcoxon considering 1- $\alpha$ of probability ( $\alpha=0.05)$ was used to determine if there are improvements in organizational practices when using the CMMI model.

\section{Results}


The following is the result of the implementation process of CMMI practices of the process areas: Requisitions Management, Verification and Validation.

\subsection{Process Improvement}

\section{Requirements Management Process Area}

The specific practices of the process area Requirements Management according to CMMI [2] are:

- SG1: Manage the Requirements

SP1.1 Obtain an Understanding of Requirements.

SP1.2 Obtain Commitment to Requirements.

SP1.3 Manage Requirements Changes.

SP1.4 Maintain Bidirectional Traceability of Requirements.

SP1.5 Ensure Alignment Between Project Work and Requirements

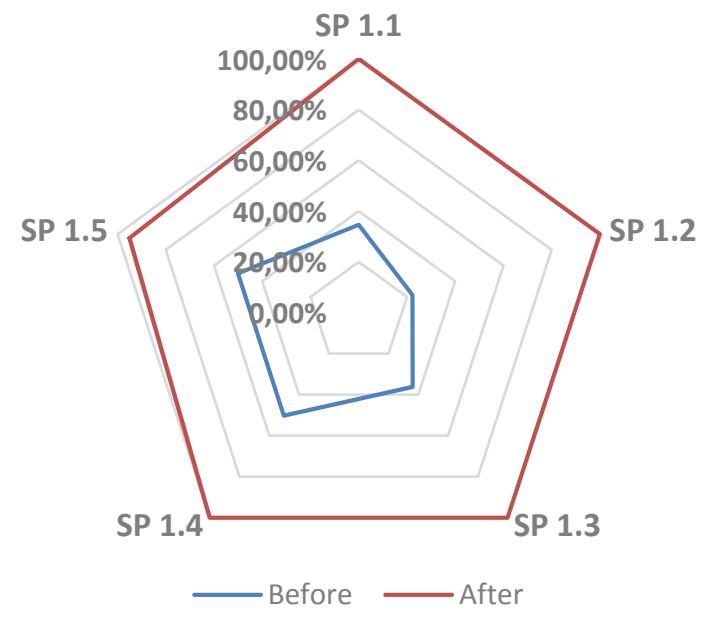

Fig 3. Gap between CMMI and organizational practices for Requirements Management

Figure 3 shows the gap that existed between the practices of the organization and after the improvement process with CMMI. All specific practices have been implemented $100 \%$. The gap between specific and generic goals is presented in [16].

The percentage of coverage of the practices is lower (52.70) than when the improvement process ends (98.83), which shows that there was an improvement in the processes. The Wilcoxon test analysis evidenced a significant difference in the percentages of coverage of the practices at the end of the improvement process.

\section{Verification Process Area}

The specific practices of the process area Verification according to CMMI [2] are:

- SG1: Prepare por Verification

SP1.1 Select Work Products for Verification.

SP1.2 Establish the Verification Environment.

SP1.3 Establish Verification Procedures and Criteria.

- SG2: Perform Peer Reviews

SP2.1 Prepare for Peer Reviews.

SP2.2 Conduct Peer Reviews.

SP2.3 Analyze Peer Review Data.

- SG3: Verify Selected Work Products

SP3.1 Perform Verification.

SP3.2 Analyze Verification Results

Figure 4 shows the gap that existed between the practices of the organization and after the improvement process with CMMI. The percentage of coverage of the practices is lower $(47,41)$ than when the improvement process ends $(98,83)$, which shows that there was an improvement in the processes.

The Wilcoxon test analysis showed a significant difference in the percentages of coverage of the practices at the end of the process of improvement.

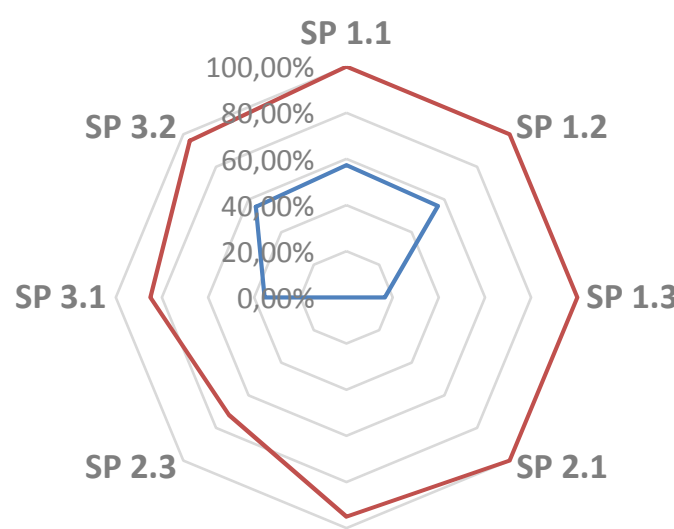

SP 2.2

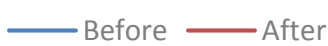

Fig 4. Gap between CMMI and Verification organization practices

All the specific practices have been implemented $100 \%$, with the exception of practices 2.2 and 2.3 where $95 \%$ and $72 \%$ were obtained respectively. In the process of continuous improvement, we will continue with the analysis of the results of the peer review such as: Types of defects detected. and Causes of defects and Impact of the resolution of defects 


\section{Validation Process Area}

The specific practices of the process area Validation according to CMMI [2] are:

- SG1: Prepare Validation

SP 1.1 Select Products for Validation.

SP 1.2 Establish the Validation Environment.

SP 1.3 Establish Validation Procedures and Criteria

- SG2: Validate Product or Product Components SP2.1 Perform Validation.

SP2.2 Analyze Validation Results.

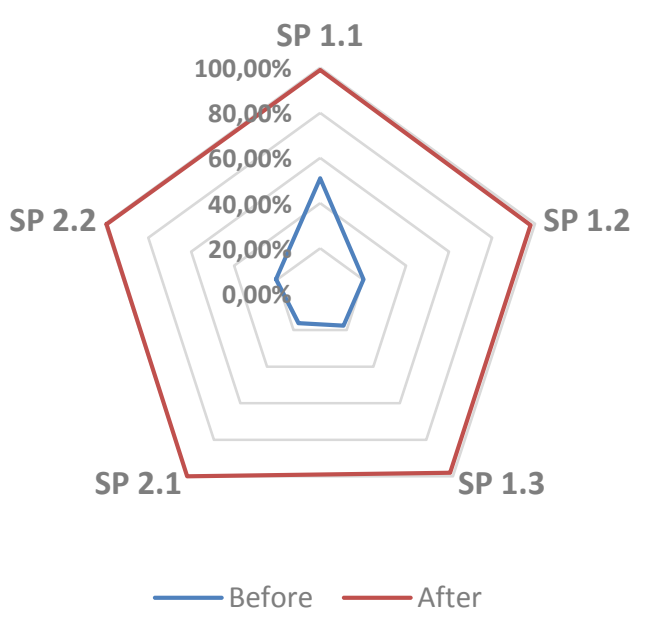

Fig. 5 Gap between CMMI and Validation organization practices
The percentage of coverage of the practices is lower $(43,50)$ than when the improvement process ends $(986,15)$, which shows that there was an improvement in the processes.

The Wilcoxon test analysis showed a significant difference in the percentages of coverage of the practices at the end of the process of improvement.

Figure 5 shows the gap between the practices of the organization and the process of improvement with CMMI.

\subsection{Improvement Process Results Surveys}

To know the results of the improvement process according to the perception of the staff and the clients, surveys were conducted. Perception is a cognitive process that consists of receiving, processing and interpreting information or a reality.

Table 3 presents the staff's perception. The results show that requirements management has been achieved, the roles and responsibilities of those responsible for the process have been defined, the change management process has been improved by evaluating its impact.

Likewise, the team's peer review is carried out to correct defects in advance.

Table 3. Results of the survey to employees

\begin{tabular}{|l|l|}
\hline Questions & Situation \\
\hline $\begin{array}{l}\text { Is there adequate requirements } \\
\text { management? }\end{array}$ & $\begin{array}{l}\text { The total number of interviewees considers that after the improvement an } \\
\text { adequate management of the requirements is carried out, since validation, } \\
\text { approval and documentation this charge of a team and it has been } \\
\text { achieved to reduce the inconsistencies that were initially proposed. }\end{array}$ \\
\hline $\begin{array}{l}\text { Is there any overtime? } \\
\begin{array}{l}\text { Is there a commitment to achieve } \\
\text { compliance by each project } \\
\text { participant? }\end{array}\end{array}$ & $\begin{array}{l}\text { The total number of interviewees considers that the commitment of } \\
\text { compliance by each area involved is established through minutes of } \\
\text { meetings. In the meetings there is active participation of the responsible } \\
\text { team. }\end{array}$ \\
\hline $\begin{array}{l}\text { Are version change requests } \\
\text { properly managed? }\end{array}$ & $\begin{array}{l}\text { The total number of interviewees considers that it is properly managed } \\
\text { when a change is requested by the client, being validated and the team } \\
\text { involved is aware of this change. }\end{array}$ \\
\hline
\end{tabular}




\begin{tabular}{|l|l|}
\hline $\begin{array}{l}\text { At the end of the project, are the } \\
\text { initial requirements achieved? }\end{array}$ & $\begin{array}{l}\text { The total number of interviewees considers that at the end of the project } \\
\text { the established requirements are achieved, as the requirements are } \\
\text { managed, verified and validated during the development of the project. }\end{array}$ \\
\hline $\begin{array}{l}\text { Are the selected work products } \\
\text { checked for suitability to achieve } \\
\text { the project requirements? }\end{array}$ & $\begin{array}{l}\text { The total number of interviewees considers that the selected work } \\
\text { products are checked for compliance with the requirements. }\end{array}$ \\
\hline $\begin{array}{l}\text { Is there pair-wise review in the } \\
\text { development team to correct } \\
\text { defects? }\end{array}$ & $\begin{array}{l}\text { The total number of interviewees said that reviews are carried out among } \\
\text { the development team to correct defects in advance. }\end{array}$ \\
\hline
\end{tabular}

In addition, a total of 15 clients were interviewed for the purpose of determining satisfaction and verifying compliance with established activities. Table 4 presents the questions and results of the interview. The results show that standardized documents are used, participation of those responsible, change in requirements is managed and its impact is evaluated, deadlines are met and peer review is conducted. All of the above is aimed at obtaining quality products and meeting customer requirements.

Tabla 4. Client survey results

\begin{tabular}{|l|l|}
\hline Questions & Situation \\
\hline $\begin{array}{l}\text { Are the requirements } \\
\text { detailed in a requirements } \\
\text { document? }\end{array}$ & $\begin{array}{l}\text { The total of the interviewees indicate that the requirements are detailed in a } \\
\text { standardized document, managing to validate the requirements. }\end{array}$ \\
\hline $\begin{array}{l}\text { Is the team involved in } \\
\text { obtaining the requirements? }\end{array}$ & $\begin{array}{l}\text { The total of the interviewees indicate that the team involved is in the process of } \\
\text { obtaining the requirements and in the meetings scheduled by the client. }\end{array}$ \\
\hline $\begin{array}{l}\text { Is a document handled for } \\
\text { the request for change in } \\
\text { requirements? }\end{array}$ & $\begin{array}{l}\text { The total number of interviewees indicate that when requesting a change, the } \\
\text { team manages a format that details the change and the impact it has. }\end{array}$ \\
\hline $\begin{array}{l}\text { Are meetings held to } \\
\text { validate requirements? }\end{array}$ & $\begin{array}{l}\text { The total number of interviewees indicate that they hold meetings to validate } \\
\text { the requirements and request for change. }\end{array}$ \\
\hline $\begin{array}{l}\text { Is the delivery of all the } \\
\text { requested requirements } \\
\text { achieved? }\end{array}$ & $\begin{array}{l}\text { The total of the interviewees indicate that after the improvement they are } \\
\text { achieving the requested requirements. }\end{array}$ \\
\hline Are the deadlines achieved? & The total number of interviewees indicates that the project team is on time. \\
\hline $\begin{array}{l}\text { Are defects found after the } \\
\text { project has been completed? }\end{array}$ & $\begin{array}{l}\text { 93.3\% of the interviewees indicated that no observations were found after the } \\
\text { project had been completed, since the validation of the requirements and the } \\
\text { necessary tests to verify that the requirements were being achieved since the } \\
\text { beginning. }\end{array}$ \\
\hline $\begin{array}{l}\text { Are you satisfied with the } \\
\text { project obtained? }\end{array}$ & $\begin{array}{l}\text { The total of the interviewees indicate that they feel satisfied after the project is } \\
\text { completed, as they obtain what they requested and on time. }\end{array}$ \\
\hline
\end{tabular}

The results show that by applying CMMI's best practices, quality products are obtained, defects are reduced and customer satisfaction is increased.
Similar results were achieved in a previous study on the application of CMMI best practices [17].

\subsection{Critical Success factors}


The implementation of CMMI's best practices is conditioned by a set of factors [12]. The following are the factors that contributed to the achievement of the objectives.

- Alignment with business objectives and strategies: It was decided to use the business activities to checklist the business objectives.

- Commitment of the Top Management: The commitment and support of the top management was achieved to conduct the improvement process.

- Shared vision: A shared vision was maintained in order to achieve the collaboration of those involved in the process.

- Infrastructure: The necessary resources for the project were ensured.

- Sponsorship of the project: based on leadership and commitment, who provided the necessary resources, designation of responsible and improvement team.

- Standards and procedures: Use of the CMMI model widely recognized, so as to benefit from the experiences of the software industry.

- Training: A training program was established for the members of the development team.

- Communication: A communication plan was established to keep staff informed of activities.

- Roles and responsibilities: Roles and responsibilities were assigned and defined for those involved in the process.

- Managing change: The implementation of CMMI is a change based on training, communication and participation.

\subsection{Aspects to take into account}

In the process of improvement, it is important to take into account some aspects:

- Observe the level of commitment and involvement of the company's team: to detect how motivated they are to achieve the goals, if there is awareness of the cost of the improvement project focused on the dedication of the human resource,

- Develop a training program according to the needs and profile of the participants that has homogeneous experience and avoid high levels of dissatisfaction for being basic and not timely.

- Develop strategies to manage knowledge that promotes collaborative learning, through the formation of teams to socialize, and discuss progress.

- Establish intermediate peer reviews as a mechanism to improve the quality of the consulting service. Promote impartiality of results and credibility.

- Adequately dimension the effort required for the adoption of best practices and provide solutions to the organization's recurring problems.

- To selectively apply the practices according to the context of the project, and to understand that it is the model that must work for the organization, avoiding that the organization works for the model.

- To keep the participants of the project permanently informed about the progress, difficulties and achievements of the Project.

\section{Conclusion}

CMMI has been recognized as a model for the improvement of processes that when used by organizations obtain quality products. In this article a case of application of the best practices of CMMI has been presented together with the IDEAL methodology for the implementation of the practices and of SCAMPI method to establish the gap between the desired level and the current one. The results show that the Requirements Management area was improved by obtaining processes, activities that helped to improve, processes and activities were defined, formats of each of the process areas. By applying the process improvement, the amount of inconsistency that was initially presented before the requirements was reduced from $56.83 \%$ to $12.13 \%$. The amount of software defects was reduced, achieving efficiency between tests, in addition to defining a process of peer testing before moving to certification. It is concluded that, when applying the process improvement, the indicator of the level of compliance of the validation area improves from $52.20 \%$ to $97.67 \%$. It is important to take into account critical success factors, as process facilitators.

\section{References:}

[1] PMI Requirements Management: a practice guide, Project Management Institute, 2016.

[2] M. Chrissis, M. Konrad, and S. Shrum, CMMI for Development ${ }^{\circledR}$ : Guidelines for Process Integration and Product Improvement. Third Edition. Addison-Wesley Professional, 2011. 
[3] IEEE

830

https://www.fdi.ucm.es/profesor/gmendez/docs is0809/ieee830.pdf.

[4] ISO/IEC 12207:2008, Information technology - Software life cycle processes. International Organization for Standardization/International Electrotechnical Commission, Geneva, Switzerland, 2008.

[5] T. Gonçalves, K. Oliveira, C. Kolski. Identifying HCI approaches to support CMMIDEV for interactive system development. Computer Standards \& Interfaces, Vol. 58, 2018, pp. 53-86.

[6] F. Ramos, Implantación de CMMI nivel de madurez 2 en una PYME, Revista española de innovación, Vol. 6, No. 3, 2010, pp. 35-46.

[7] A. Serrano, Metgamodelo para la mejora de procesos de gestión de requisitos. Madrid: Universidad Politecnica de Madrid, 2013.

[8] L. Torres, M. Dunia, D. Rodriguez, D. Gómez, and Y. Alonso, Entorno de ingeniería de requisitos aplicado para producir software en una universidad. Madrid: Complejo de Investigaciones tecnológicas integradas, 2014.

[9] CHAOS, The Standish Group International. Chaos manifesto, 2013.

[10] A. Rocha, and J. Freixo, Information Architecture for Quality Management Support in Hospitals, Journal of Medical Systems, Vol. 39, No.10, 2015, pp. 1-11.

[11] SEI. The IDEAL model. New York: Software Engineering Institute, 2009.
[12] S. Bayona-Oré, J. Calvo-Manzano, G. Cuevas, and T. San-Feliu, Critical success factors taxonomy for software process deployment. Software Quality Journal, Vol. 22, No. 1, 2014, pp. 21-48.

[13] M. Piattini, F. García, I. García Rodríguez, F. Pino, Calidad de Sistemas de Información. Segunda edición, Madrid: Rama, 2014.

[14] F. Pires da Silva, H. Mateus, P. Rino, Leadership competencies revisited: A causal configuration analysis of success in the requirements phase of information systems projects. Journal of Business Research, Vol. 101, 2019, pp. 688-696.

[15] S. McIntyre, Utilizing Evidence-Based Lessons Learned for Enhanced Organizational Innovation and Change, IGI Global, 2014.

[16] S. Bayona-Oré, J. Chamilco, D. Perez, Applying CMMI Best Practices to Improve Processes, MATEC Web Conf., Vol. 292, 2019, pp. 1-6.

[17] A. Chavarría, S. Bayona, C. Pastor. Aseguramiento de la Calidad en el Proceso de Desarrollo de Software utilizando CMMI, TSP y PSP. RISTI - Revista Ibérica de Sistemas e Tecnologias de Informação, Vol. 20, 2016, pp. 62-77. 